\title{
Institutionalized elderly people with dementia: an integrative review on nursing care
}

\author{
Idosos com demência institucionalizados: revisão integrativa sobre os cuidados de enfermagem \\ Ancianos con demencia institucionalizados: revisión integrativa sobre los cuidados de enfermería
}

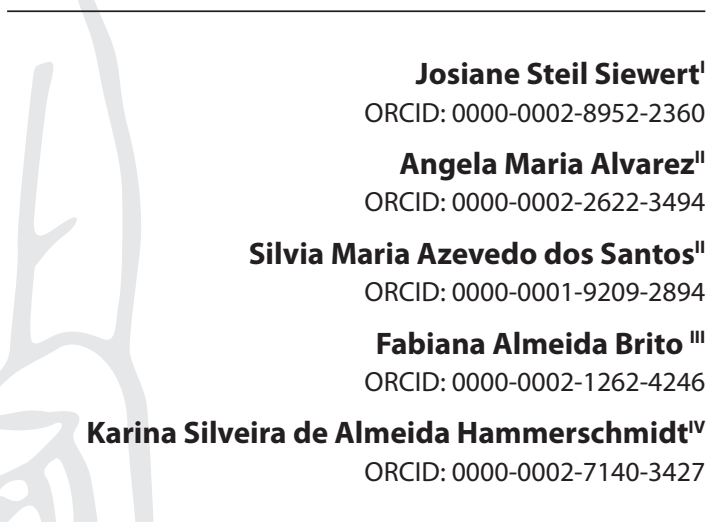

'Instituto Federal de Santa Catarina. Joinville, Santa Catarina, Brazil.

"Universidade Federal de Santa Catarina. Florianópolis, Santa Catarina, Brazil.

II' University of Nebraska Medical Center. Omaha, Nebraska,

Estados Unidos da América.

" Universidade Federal do Paraná. Curitiba, Paraná, Brazil

How to cite this article:

Siewert JS, Alvarez AM, Santos SMA, Brito FA, Hammerschmitdt KSA. Institutionalized elderly people with dementia: an integrative review on nursing care.

Rev Bras Enferm. 2020;73(Suppl 3):e20180419. doi: http://dx.doi.org/10.1590/0034-7167-2018-0419

\section{Corresponding author: Josiane Steil Siewert \\ E-mail: josianes@ifsc.edu.br}

EDITOR IN CHIEF: Dulce Barbosa ASSOCIATE EDITOR: Maria Saraiva

Submission: 07-03-2018

Approval: 05-11-2020

\section{ABSTRACT}

Objective: To ascertain the characteristics of the nursing care provided to institutionalized elderly people with dementia. Methods: Integrative review of studies published between 2013 and 2017, in English, Spanish, and Portuguese, from the databases BDENF, LILACS, CINAHL, PubMed, SciELO, TRIP, and National Guideline Clearing House. Thematic data analysis was used. Results: From the data collected in the 41 included studies, three themes emerged: Care with a focus on the needs of elderly people in LTCIEs; Care based on the work process of the nursing team; and Shared care. Final considerations: Elderly care can take place from different perspectives: that of the elderly; the nursing team; and it can be shared among the different parties involved. The importance of communication must be stressed, as do the development of skills and attitudes of the team, as well as proper training and support, good environment in the care process, and an approach centered on the institutionalized elderly. Descriptors: Nursing care; Dementia; Nursing; Elderly People; Long-Term Institutions for the Elderly.

\section{RESUMO}

Objetivo: Conhecer os cuidados de enfermagemaidosos com demência institucionalizados. Método: Revisão integrativa, nas bases de dados BDENF, LILACS, CINAHL, PubMed, SciELO, TRIP e National Guideline Clearing House, de estudos publicados entre 2013 e 2017, em inglês, espanhol e português. Usou-se a análise temática dos dados. Resultados: Dos dados coletados nos 41 estudos incluídos, emergiram três temas: Cuidado com foco nas necessidades da pessoa idosa nas ILPIs; Cuidado baseado no processo de trabalho da equipe de enfermagem; e Cuidado compartilhado. Considerações finais: $\mathrm{O}$ cuidado ao idoso pode acontecer de diferentes perspectivas: do idoso; da equipe de enfermagem; ou do compartilhamento entre as diferentes partes envolvidas. Destaca-se a importância da comunicação, do desenvolvimento de habilidades e atitudes da equipe, da necessidade de treinamento e suporte para ela, do papel do ambiente no processo de cuidado, e ainda, da utilização de uma abordagem centrada no idoso institucionalizado.

Descritores: Cuidados de Enfermagem; Demência; Enfermagem; Idoso; Instituições de Longa Permanência para Idosos.

\section{RESUMEN}

Objetivo: Conocer los cuidados de enfermería a los ancianos con demencia institucionalizados. Método: Revisión integrativa, en las bases de datos BDENF, LILACS, CINAHL, PubMed SciELO, TRIP y National Guideline Clearing House, de estudios publicados entre 2013 y 2017, en inglés, español y portugués. Se utilizó el análisis temático de los datos. Resultados: De los datos recogidos en los 41 estudios inclusos, emergieron tres temas: Cuidado con foco en las necesidades de la persona anciana en las ILPIs; Cuidado basado en el proceso de trabajo del equipo de enfermería; y Cuidado compartido. Consideraciones finales: El cuidado al anciano puede ocurrir de diferentes perspectivas: del anciano; del equipo de enfermería; o del compartimiento entre las diferentes partes envueltas. Se destaca la importancia de la comunicación, del desarrollo de habilidades y actitudes del equipo, de la necesidad de entrenamiento y suporte para estos, del papel del ambiente en el proceso de cuidado, y aún, de la utilización de un abordaje centrado en el anciano institucionalizado.

Descriptores: Cuidados de Enfermería; Demencia; Enfermería; Anciano; Instituciones de Larga Permanencia para Ancianos. 


\section{INTRODUCTION}

Currently, there are 50 million people living with some form of dementia, from which $60 \%$ live in low- or middle-income countries ${ }^{(1)}$. The demand for care for the elderly with dementia has transcended the family scope and become a public health issue. Dementia is characterized by developing over the years and compromises at least one of these functions: attention; executive functioning; learning and memory; language; motor perception; social cognition ${ }^{(2)}$.

Long-term care institutions for the elderly (LTCIEs) are a growing option for families that are no longer able to maintain home care for their family members in a dementia process. In Brazil, amongst the population of elderly over 60 years old, only $0.6 \%$ live in these institutions, which in general also offer healthcare for people with higher degrees of dependence associated with the comorbidities characteristic of aging. However, the same authors identified that most dependent elderly people are in private-type LTCIEs, reaching a proportion of $86.3 \%$ among residents and requiring trained personnel to take care of them ${ }^{(3)}$. Despite the need for health care, a study carried out in Rio de Janeiro found an index of $88.02 \%$ of institutions that have technical nursing activities without the supervision of nurses, which goes against the Law of Professional Nursing Practice ${ }^{(4-5)}$.

A study carried out in southern Brazil found that the factors that have predisposed the elderly to institutionalization were: absence of spouse and children, cognitive impairment and dependence for basic activities of daily living, in addition to diseases associated with cognitive and functional impairments, such as Alzheimer's and Parkinson's diseases, other unspecified dementias, and stroke motor sequelae ${ }^{(6)}$.

Considering the accelerated aging process of the Brazilian population and its demands, it is essential to prepare nursing professionals to work in the context of LTCIEs, guaranteeing safe and quality care for the people who live and receive cared in these institutions. Thus, this integrative review sought to answer the following research question: What is the scientific knowledge produced by nursing when it comes to caring for elderly people with dementia who live in LTCIE? It aimed to know the scientific production on nursing care for elderly people with dementia in long-term institutions during the last five years.

Scientific knowledge about the care provided to elderly people with dementia in LTCIEs may help to improve the assistance provided, given that these institutions are unique care environments, as they blend the characteristics of residence and healthcare institution, offering a growing field of action for nursing professionals. Therefore, it is urgent to know the scientific production available to support an evidence-based nursing practice, and to develop assistance with the quality and safety required by the complexity of the theme.

\section{OBJECTIVE}

To ascertain the scientific production on nursing care for the elderly with dementia in long-term institutions during the last five years.

\section{METHODS}

This integrative review ${ }^{(7)}$ followed these steps: elaboration of the research question; sampling and literature search; categorization of studies and evaluation of those included in the review; interpretation of results and summary of the review.

The databases selected for this study were: Nursing Database (BDENF), Latin American and Caribbean Health Sciences Literature (LILACS), National Library of Medicine (PubMed), SciVerse Scopus, Cumulative Index to Nursing and Allied Health Literature (CINAHL), accessed by the Portal CAPES, Scientific Eletronic Library Online (Scielo), Trip and National Guideline Clearing House. The search strategies were set up according to the researched bases, using the descriptors "Elderly", "Nursing Care", "Long Term Care Institution for the Elderly", and "Dementia", as found in the Health Science Descriptors (DeCS / Bireme) or Medical Subject Headings (MeSH / PubMed). For all descriptors, their correspondents in English and Spanish were used, with keywords in the three languages (Portuguese, English, and Spanish).

The inclusion criteria were: complete articles, guidelines and clinical protocols published in the last five years that address nursing care for elderly people with dementia residing in LTCIEs. The selected languages were English, Portuguese, and Spanish; the methodology could be quantitative, qualitative, or mixed. Exclusion criteria: care provided by other professionals or in other contexts, reflection articles, editorials, theses and dissertations.

Through the search strategy established in the different databases, 557 publications were found. The studies were selected in December 2017 and analyzed in January 2018. To better organize the process, the selection was carried out in stages, starting with the reading of the titles and abstracts (Chart 1).

Chart 1 - Flowchart for the selection of articles in the databases

\begin{tabular}{|c|c|c|c|c|c|c|c|}
\hline Step & \multicolumn{7}{|l|}{ Description } \\
\hline Research question & \multicolumn{7}{|c|}{ What is the scientific production on nursing care for elderly people with dementia living in long-term institutions in the last five years? } \\
\hline \multirow{2}{*}{ Identification of articles } & $\begin{array}{l}\text { PubMed } \\
\quad 97\end{array}$ & $\begin{array}{l}\text { Scopus } \\
52\end{array}$ & $\begin{array}{l}\text { SciELO } \\
30\end{array}$ & $\begin{array}{l}\text { LILACS / BDEFN } \\
\qquad 210\end{array}$ & $\begin{array}{l}\text { CINAHL } \\
\quad 44\end{array}$ & $\begin{array}{l}\text { National Guidelines } \\
\qquad 82\end{array}$ & $\begin{array}{l}\text { Trip } \\
42\end{array}$ \\
\hline & \multicolumn{7}{|c|}{557 articles retrieved using search strategy } \\
\hline $1^{\text {st }}$ Selection step & \multicolumn{7}{|c|}{$\begin{array}{l}493 \text { articles were excluded for not meeting the inclusion criteria or for being duplicates. } \\
60 \text { articles were selected for full reading. }\end{array}$} \\
\hline $2^{\text {nd }}$ Selection step & \multicolumn{7}{|c|}{19 articles were excluded for not meeting the inclusion criteria. } \\
\hline $3^{\text {rd }}$ Selection step & \multicolumn{7}{|c|}{41 articles were included and analyzed in the review. } \\
\hline
\end{tabular}


Chart 2 - Example of the thematic analysis codification process

\begin{tabular}{|c|l|l|l|}
\hline $\begin{array}{c}\text { Id } \\
\text { article }\end{array}$ & Selection of units of analysis & $\begin{array}{l}\text { Units of } \\
\text { meaning }\end{array}$ & Themes \\
\hline 19 & $\begin{array}{l}\text { In the care model Goals of Care, } \\
\text { explanatory videos were presented } \\
\text { to family members, so they would } \\
\text { know the goals of care and the } \\
\text { treatments available for each goal } \\
\text { to be achieved. They chose what } \\
\text { goals they wanted for their relatives } \\
\text { from the treatments available. } \\
\text { Subsequently, the nursing team } \\
\text { discussed the choices with family } \\
\text { members, deciding together what } \\
\text { would be best for the elderly. }\end{array}$ & $\begin{array}{l}\text { Family } \\
\text { involvement }\end{array}$ & $\begin{array}{l}\text { Shared } \\
\text { care }\end{array}$ \\
\hline
\end{tabular}

Data were collected using an instrument prepared by the authors, which consisted of a table with the following items: identification of the article, year and journal of publication, place (country) of execution, objectives, nature of the research, theoretical framework, type of study, nursing care, main results, and conclusion. These elements made it possible to organize and synthesize the information contained in the articles.

The characterization of the studies was followed by the chosen thematic analysis, starting with a comprehensive and exhaustive reading of the texts, in order to obtain a global view of the set ${ }^{(8-9)}$. Then, a new interpretive reading was carried out seeking convergences and composing subsets, which resulted in multiple units of meaning. In the last stage, the units of meaning that presented connection points for dialogues were grouped and the broader themes were elaborated ${ }^{(8-9)}$.

The three themes that emerged from the approach used for the nursing care performed were: Care with a focus on the needs of elderly people in LTCIEs; Care based on the work process of the nursing team; and Shared care.

\section{RESULTS}

\section{Characterization of studies}

The year with the largest number of publications was 2016, with $31.7 \%$ of articles (13), followed by $2014-24.4 \%$ (10); 2015 - 22\% (9); 2013 - 14.6\% (6); and 2017 - 7.3\% (3). Excepting 2017, there has been a growing distribution of publications in the last five years, which demonstrates a continued interest and the need to produce knowledge in this area.
Regarding the place where the studies were carried out, there are 12 different countries: first, the United States, with $24.4 \%$ (10), followed by Australia, with 17\% (7); Sweden and the Netherlands, with $9.7 \%$ (4) each; Germany and the United Kingdom, with $7.3 \%$ (3); and Norway, with 4.8\% (2). The other countries were: Canada, Spain, Finland, England, South Korea, and Wales. In two studies, there was no country of origin. In the databases used, no Brazilian studies published in the period were identified that met the inclusion criteria.

As for the nature of the research, the quantitative methodology represented $44 \%$ (18), followed by qualitative investigations, with $31.7 \%$ (13); in $19.5 \%$ (8), there was no statement of the nature of the research used, and in $4.8 \%$ (2), mixed methods were employed. Accordingly, the main type of study was the randomized clinical trial, present in $22 \%$ (9) of the studies. For the other results, there was great variation in typology, with descriptive studies and interviews predominating, with $12.2 \%$ (5) each.

Most studies, $63.4 \%$ (26), did not state the theoretical framework used. Among the studies that declared it, it was related to some model of care, Person Centred Care (PCC) being the most present, with 17\% (7). The other references mentioned were: Communication Enhancement Model; Ethno-Cultural Gerontological Nursing (ECGN) Model; Progressively Lowered Stress Threshold Model; Function-Focused Care (FFC); Goals of Care; Marte Meo Counselling; Self-Determination Theory (SDT); Broaden-and-Build Theory and Madeleine Leininger's theory of cross-cultural care. The theories presented here have a foreign origin and are almost unknown to national nursing, with the exception of Leininger's theory of cross-cultural care.

Among the problems or health problems related to dementia, behavioral problems were the main concern in $24.4 \%$ (10) of the studies, followed by communication and different other problems, with $14.6 \%$ (6) for each; and problems with basic human needs, with $9.7 \%$ (4). The other health problems mentioned were related to: physical disability, loss of autonomy, polypharmacy, pain, patient safety, quality of life, encouragement for family participation, palliative care and ethical issues in the care of institutionalized elderly. These data show that, even a specific health problem, such as dementia, involves several aspects that need to be studied and understood for safe and quality nursing care to be provided.

In Chart 3, the 41 articles are shown, with their identification, authors, year of publication, nursing care, and main outcomes.

Chart 3 - Selected Articles

\begin{tabular}{|l|l|l|}
\hline Authors and year & Nursing care & Outcome \\
\hline $\begin{array}{l}\text { Van Haitsma KS, Curyto } \\
\text { K, Abbot KM, Towsley GL, } \\
\text { Spector A, Kleban M. 2015(10) }\end{array}$ & $\begin{array}{l}\text { Carry out daily activities with } \\
\text { the elderly, but always in their } \\
\text { interest }\end{array}$ & $\begin{array}{l}\text { Both the individualized positive psychosocial intervention groups and the individualized } \\
\text { intervention group with the nurse experienced similar benefits - they were more alert, } \\
\text { involved, had positive touches and a positive verbal behavior compared to the usual care } \\
\text { group. The group with individual care showed more negative behaviors, anger, lack of } \\
\text { cooperation, than the group of psychosocial intervention and the usual care group. }\end{array}$ \\
\hline $\begin{array}{l}\text { McCabe MP, Bird M, Davison } \\
\text { TE, Mellor D, MacPherson S, } \\
\text { Hallford D, et al. 2015 }{ }^{(11)} .\end{array}$ & $\begin{array}{l}\text { Identify the possible causes } \\
\text { of behavioral problems } \\
\text { associated with dementia }\end{array}$ & $\begin{array}{l}\text { The results demonstrated the effectiveness of using the behavioral problems } \\
\text { protocol for reducing the elderly's behavioral problems and the team's stress, } \\
\text { improving self-efficacy. }\end{array}$ \\
\hline $\begin{array}{l}\text { Tjia J, Hunnicutt JN, Herndon } \\
\text { L, Blanks CR, Lapane KL, } \\
\text { Wehry S. 2017 }{ }^{(12)} \text {. }\end{array}$ & $\begin{array}{l}\text { Meet the daily needs of } \\
\text { the elderly through a care } \\
\text { program }\end{array}$ & $\begin{array}{l}\text { The program helped to reduce the use of antipsychotics during the intervention } \\
\text { period, but this decrease did not continue during the conservation stage. However, } \\
\text { there was no increase in the use of psychotropics or in the occurrence of behavioral } \\
\text { problems. The evidence suggests the use of non-pharmacological interventions to } \\
\text { treat the behavioral and psychological symptoms of dementia. }\end{array}$ \\
\hline
\end{tabular}




\begin{tabular}{|c|c|c|}
\hline Authors and year & Nursing care & Outcome \\
\hline $\begin{array}{l}\text { Hall GR, Gallagher M, } \\
\text { Hoffmann-Snyder C. } 2013^{(13)} \text {. }\end{array}$ & $\begin{array}{l}\text { Bathing techniques for } \\
\text { patients with dementia }\end{array}$ & $\begin{array}{l}\text { Decrease in the frequency and severity of negative episodes during the bath of } \\
\text { patients with dementia. }\end{array}$ \\
\hline $\begin{array}{l}\text { Jutkowitz, E, Brasure M, } \\
\text { Fuchs E, Shippee T, Kane RA, } \\
\text { Fink HA, et al. } 2016^{(14)} \text {. }\end{array}$ & $\begin{array}{l}\text { Non-pharmacological } \\
\text { interventions to control } \\
\text { agitation and aggression in } \\
\text { patients with dementia }\end{array}$ & $\begin{array}{l}\text { There is insufficient evidence on the effectiveness of care provided through non- } \\
\text { pharmacological interventions to reduce agitation or aggression in long-term care } \\
\text { facilities. }\end{array}$ \\
\hline $\begin{array}{l}\text { Söderman M, Rosendahl SP. } \\
2016^{(15)} \text {. }\end{array}$ & $\begin{array}{l}\text { Verbal and non-verbal } \\
\text { communication and cultural } \\
\text { activities for elderly from } \\
\text { different cultures }\end{array}$ & $\begin{array}{l}\text { Although the nursing team that did not speak the same language as the elderly } \\
\text { could provide care with equal quality, it was more difficult for them than for the team } \\
\text { whose members were able to communicate in the language of the elderly. }\end{array}$ \\
\hline $\begin{array}{l}\text { Roberts G, Morley C, Walters } \\
\text { W, Malta S, Doyle C. } 2015^{(16)} \text {. }\end{array}$ & $\begin{array}{l}\text { Care model that promotes } \\
\text { activities based on the } \\
\text { preferences of the elderly, } \\
\text { considering their life history }\end{array}$ & $\begin{array}{l}\text { The team reported increased knowledge about meeting the needs of people with } \\
\text { dementia and changing organizational culture, demonstrating the efficiency of the } \\
\text { model. The families were very pleased with the changes. }\end{array}$ \\
\hline $\begin{array}{l}\text { Sprangers S, Dijkstra K, } \\
\text { Romijn-Luijten A. } 2015^{(17)} \text {. }\end{array}$ & \begin{tabular}{|l|} 
Communication between \\
nursing and the elderly \\
\end{tabular} & $\begin{array}{l}\text { Lower stress rate for the team and increased use of short instructions and positive } \\
\text { communication between the team and the elderly. }\end{array}$ \\
\hline $\begin{array}{l}\text { Rodriguez-Martín B, } \\
\text { Martínez-Andres M, Notario- } \\
\text { Pacheco B, Martínez-Vizcaíno } \\
\text { V. } 2016^{(18)} \text {. }\end{array}$ & $\begin{array}{l}\text { Communication and } \\
\text { interaction skills with the } \\
\text { elderly with dementia }\end{array}$ & $\begin{array}{l}\text { Due to the tendency of technification of care, families demand personalized and } \\
\text { small-scale attention, in which they themselves are an active part of the care process. }\end{array}$ \\
\hline $\begin{array}{l}\text { Soderlund M, Cronqvist A, } \\
\text { Norberg A, Ternestedt B, } \\
\text { Hansebo B. } 2016^{(19)} \text {. }\end{array}$ & $\begin{array}{l}\text { Communication skills with the } \\
\text { elderly with dementia }\end{array}$ & $\begin{array}{l}\text { Considering the positive results after the intervention, the training given to nurses } \\
\text { on communication may have improved their communication skills with elderly } \\
\text { people with dementia. }\end{array}$ \\
\hline $\begin{array}{l}\text { Registered Nurses Association } \\
\text { of Ontario. } 2016^{(20)} \text {. }\end{array}$ & $\begin{array}{l}\text { Guideline care for patients } \\
\text { with dementia }\end{array}$ & $\begin{array}{l}\text { This document provides numerous evidence-based interventions (through } \\
\text { systematic reviews) in various areas of nursing care for elderly people with dementia. }\end{array}$ \\
\hline $\begin{array}{l}\text { Palm R, Trutschel D, Simon M, } \\
\text { Bartholomeyczik S, Holle B. } \\
2016^{(21)} \text {. }\end{array}$ & Case study & $\begin{array}{l}\text { Case discussion is an intervention widely used in institutions for the elderly in } \\
\text { Germany as a way to treat behavioral problems of dementia, with no distinction } \\
\text { between traditional and specialized units. }\end{array}$ \\
\hline $\begin{array}{l}\text { Karel MJ, Teri L, McConnel E, } \\
\text { Visnic S, Karlin BE. } 2016^{(22)} \text {. }\end{array}$ & $\begin{array}{l}\text { Program to address the } \\
\text { behavioral effects of dementia }\end{array}$ & $\begin{array}{l}\text { Frequency and severity of target behaviors and symptoms of depression, anxiety } \\
\text { and restlessness decreased significantly. The team assessed the benefits for patients, } \\
\text { considering the program feasible. }\end{array}$ \\
\hline $\begin{array}{l}\text { Van de Ven G, Draskovic I, } \\
\text { Adang EMM, Donders R, } \\
\text { Zuidema SU, Koopmans } \\
\text { RTCM, et al. } 2013^{(23)} \text {. }\end{array}$ & Nursing care model & $\begin{array}{l}\text { Findings did not confirm the effect on the primary outcome of agitation. Perhaps the } \\
\text { model's nature, with such a variable and extensive implementation, explains this lack } \\
\text { of effect. }\end{array}$ \\
\hline $\begin{array}{l}\text { Moyle W, Venturato L, Cooke } \\
\text { M, Murfield J, Griffiths S, } \\
\text { Hughes J, et al. } 2016^{(24)}\end{array}$ & Nursing care model & $\begin{array}{l}\text { Despite the several limitations that the study has, the model appears to be more } \\
\text { effective for providing dementia care than usual practice. The model should be } \\
\text { evaluated in greater depth with participants from a diverse range of institutions and } \\
\text { different stages of cognitive impairment. }\end{array}$ \\
\hline $\begin{array}{l}\text { Cooke M, Moyle W, Venturato L, } \\
\text { Walters C, Kinnane J. } 2014^{(25)} \text {. }\end{array}$ & Elderly care model & $\begin{array}{l}\text { The results suggest that the education protocol had positive impacts on participants' } \\
\text { knowledge, skills, and attitudes, providing quality dementia care to residents. }\end{array}$ \\
\hline $\begin{array}{l}\text { Park M, Lim S, Kim E, Lee S, } \\
\text { Chang S. } 2017^{(26)} \text {. }\end{array}$ & $\begin{array}{l}\text { Promote elderly's physical } \\
\text { capacities }\end{array}$ & $\begin{array}{l}\text { The evidence provided new ideas for developing specialized nursing interventions } \\
\text { and practical nursing models for elderly care institutions. }\end{array}$ \\
\hline $\begin{array}{l}\text { Kovach CR, Hekel B, Rababa } \\
\text { M. } 2015^{(27)} \text {. }\end{array}$ & $\begin{array}{l}\text { Protocol to track and suspend } \\
\text { ineffective treatments }\end{array}$ & $\begin{array}{l}\text { The protocol was evaluated as useful and easy, although the nurses showed some } \\
\text { difficulty in keeping the information organized. }\end{array}$ \\
\hline $\begin{array}{l}\text { Hanson LC, Song MK, } \\
\text { Zimmerman S, Gilliam R, } \\
\text { Rosemond C, Chisholm L et } \\
\text { al. } 2016^{(28)} \text {. }\end{array}$ & Elderly care model & $\begin{array}{l}\text { The methods used to ensure fidelity to the intervention were effective and allowed } \\
\text { the model to be adopted and implemented by the nursing team. In the end, } 69 \% \text { of } \\
\text { the discussions between the family and the team were implemented. }\end{array}$ \\
\hline $\begin{array}{l}\text { Rosendahl SP, Söderman M, } \\
\text { Mazaheri M. } 2016^{(29)} \text {. }\end{array}$ & $\begin{array}{l}\text { Communication skills and } \\
\text { cultural adaptation }\end{array}$ & $\begin{array}{l}\text { The family member is essential in the life of immigrants with dementia residing in an } \\
\text { institution. They make it easier for nursing staff to communicate with the person with } \\
\text { dementia. }\end{array}$ \\
\hline $\begin{array}{l}\text { Allen VJ, Methven L, Gosney } \\
\text { M. 2014 } \\
\end{array}$ & Means for serving water & $\begin{array}{l}\text { A liquid nutritional supplement should be administered to people with dementia in } \\
\text { a glass or a glass with a straw. }\end{array}$ \\
\hline $\begin{array}{l}\text { Krumm N, Larkin P, Connolly } \\
\text { M, Rode P, Elsner F. 2014 }\end{array}$ & Palliative care model & $\begin{array}{l}\text { The tool presented has the potential to improve palliative care for people with } \\
\text { dementia. }\end{array}$ \\
\hline $\begin{array}{l}\text { Finucane AM, Stevenson B, } \\
\text { Moyes R, Oxenham D, Murray } \\
\text { SA. } 2013^{(32)}\end{array}$ & Palliative care model & $\begin{array}{l}\text { Despite the increase in adopting essential palliative care tools, the number of } \\
\text { hospital deaths increased during the project's development. In order to incorporate } \\
\text { palliative care, the presence of specialists in the field and nurses is essential, in } \\
\text { addition to project management and leadership. }\end{array}$ \\
\hline $\begin{array}{l}\text { Koskenniemi J, Leino-kilpi H, } \\
\text { Suhonen R. 2015 } \\
\end{array}$ & $\begin{array}{l}\text { Human treatment for the } \\
\text { elderly }\end{array}$ & $\begin{array}{l}\text { Respect in long-term care settings is manifested in patient care, through the nurses' } \\
\text { presence and actions. }\end{array}$ \\
\hline $\begin{array}{l}\text { Jordan S, Gabe M, Newson L, } \\
\text { Snelgrove S, Panes G, Picek } \\
\text { A, et al. 2014 }\end{array}$ & Drug monitoring program & Participants benefited from monitored medication systematized by nurses. \\
\hline
\end{tabular}




\begin{tabular}{|c|c|c|}
\hline Authors and year & Nursing care & Outcome \\
\hline $\begin{array}{l}\text { Jordan S, Gabe-Walter ME, } \\
\text { Watkins A, Humphreys I, } \\
\text { Newson L, Snelgrove S, et al. } \\
2015^{(35)} \text {. }\end{array}$ & Drug monitoring program & $\begin{array}{l}\text { The program can improve the quality and safety of care; it deserves further } \\
\text { investigation as a strategy to mitigate the known adverse effects of prescription } \\
\text { drugs. }\end{array}$ \\
\hline $\begin{array}{l}\text { Kim H, Woods DL, Phillips LR, } \\
\text { Ruiz ME, Salem B, Jeffers- } \\
\text { Skrine K, et al. 2015 } \\
\end{array}$ & $\begin{array}{l}\text { Communication with elderly } \\
\text { people of other ethnicities }\end{array}$ & $\begin{array}{l}\text { The model provides guidance on how to improve care and quality of life for residents } \\
\text { of different racial and cultural groups. }\end{array}$ \\
\hline $\begin{array}{l}\text { Murphy JL, Holmes J, Brooks } \\
\text { C. } 2017^{(37)} \text {. }\end{array}$ & Nutritional care model & This model can help formulating new training and education tools. \\
\hline $\begin{array}{l}\text { Lykkeslet E, Gjengedal E, } \\
\text { Skrondal T, Storjord M. } 2016^{(38)} \text {. }\end{array}$ & $\begin{array}{l}\text { Communication model with } \\
\text { the elderly }\end{array}$ & $\begin{array}{l}\text { Through this model, professionals discovered the value of considering the context of } \\
\text { patients. }\end{array}$ \\
\hline $\begin{array}{l}\text { Galik E, Resnik B, Hammersla } \\
\text { M, Brightwater J. 2014 (39). }\end{array}$ & $\begin{array}{l}\text { Care model with emphasis on } \\
\text { mobility and physical activity }\end{array}$ & $\begin{array}{l}\text { Elderly people with severely impaired cognition can be involved in physical and } \\
\text { functional activities. }\end{array}$ \\
\hline $\begin{array}{l}\text { Boekhorst ST, Depla MFIA, } \\
\text { Francke AL, Twisk JWR, } \\
\text { Zwijsen SA, Hertogh CMPM. } \\
2013^{(40)} \text {. }\end{array}$ & Electronic surveillance & $\begin{array}{l}\text { The residents' quality of life is not related to the use of electronic security, but to the } \\
\text { use of physical restrictions. }\end{array}$ \\
\hline $\begin{array}{l}\text { Fitzsimmons S, Barba B, } \\
\text { Stump M. } 2014^{(41)} \text {. }\end{array}$ & $\begin{array}{l}\text { Non-pharmacological sensory } \\
\text { interventions }\end{array}$ & $\begin{array}{l}\text { In order to treat the behavioral and psychological symptoms of dementia, nursing } \\
\text { must strive to identify non-pharmacological actions that are meaningful, easy to } \\
\text { apply and easily accepted by the elderly. }\end{array}$ \\
\hline $\begin{array}{l}\text { Peisah C, Weaver J, Wong L, } \\
\text { Strukovski J. 2014 }\end{array}$ & $\begin{array}{l}\text { Pain assessment and } \\
\text { management }\end{array}$ & $\begin{array}{l}\text { Early and proactive pain care is recommended to address behavioral and } \\
\text { psychological symptoms in dementia. }\end{array}$ \\
\hline $\begin{array}{l}\text { Mansah M, Coulon L, Bronw } \\
\text { P, Reynolds H, Kissiaw S. } \\
2014{ }^{(43)} \text {. }\end{array}$ & Elderly care model & $\begin{array}{l}\text { The study highlighted the usefulness of offering training to professionals as a } \\
\text { strategy to encourage the development of creative care for residents with dementia. }\end{array}$ \\
\hline $\begin{array}{l}\text { Rokstad AM, Rosvik J, } \\
\text { Kirkevold O, Selbaek G, } \\
\text { Saltyte Benth J Enfedal K, } \\
2013^{(44)} \text {. }\end{array}$ & Two elderly care models & $\begin{array}{l}\text { Two models of care for the elderly were tested, though no significant results were } \\
\text { found for the primary outcome (agitation). Secondary outcomes: neuropsychiatric } \\
\text { symptoms, psychotic symptoms, depression (only one of the models) and quality of } \\
\text { life (only one of the models), obtained positive results. }\end{array}$ \\
\hline $\begin{array}{l}\text { Lejman E, Westerbotn M, } \\
\text { Poder U, Wadensten B. } \\
2013^{(45)} \text {. }\end{array}$ & Physical restrictions & $\begin{array}{l}\text { Despite legal restrictions, nurses still used restrictions as a way to ensure quality and } \\
\text { safety in care. }\end{array}$ \\
\hline $\begin{array}{l}\text { Fetherstonhaugh D, Tarzi L, } \\
\text { Bauer M, Nay R, Beattie E. } \\
2016^{(46)} \text {. }\end{array}$ & $\begin{array}{l}\text { Aid to the elderly in the } \\
\text { decision-making process }\end{array}$ & $\begin{array}{l}\text { The knowledge of the workers about the elderly should be used to facilitate } \\
\text { decision-making in the care of dementia. One must be careful so that this knowledge } \\
\text { is not used to manipulate them. }\end{array}$ \\
\hline $\begin{array}{l}\text { Niemeijer AR, Depla M, } \\
\text { Frederiks B, Francke AL, } \\
\text { Hertogh C. 2014 } \\
\end{array}$ & Electronic surveillance & $\begin{array}{l}\text { Institutions wishing to implement surveillance technology should encourage the } \\
\text { dialogue about how team members see and understand the concepts of autonomy } \\
\text { and risk for the elderly. }\end{array}$ \\
\hline Harris M, Grando V. 2014(48). & Sleep patterns & $\begin{array}{l}\text { The results suggest that bedtime can be influenced by night tasks. Meeting these } \\
\text { unique sleep patterns can facilitate the development of non-pharmacological forms } \\
\text { of interventions to build sleep cycles around individual preferences and institutional } \\
\text { routines. }\end{array}$ \\
\hline $\begin{array}{l}\text { Lautenbacher S, Sampson EL, } \\
\text { Pahl S, Kunz M. } 2016^{(49)} \text {. }\end{array}$ & Pain evaluation & $\begin{array}{l}\text { Although nurses used all facial descriptors, some were used more frequently than } \\
\text { others to infer whether a resident with dementia was in pain. }\end{array}$ \\
\hline $\begin{array}{l}\text { Kolanowski A, Van haitsma } \\
\text { KS, Penrod J, Hill N, Yevchak } \\
\text { A. } 2015^{(50)} \text {. }\end{array}$ & Elderly care model & $\begin{array}{l}\text { To improve the use of the model, the flow of information exchange requires: } \\
\text { inclusion of all professionals, communication systems that consider available } \\
\text { resources, development of educational programs; investment in nursing leadership } \\
\text { to effect these changes; and financial approaches to encourage cultural change. }\end{array}$ \\
\hline
\end{tabular}

\section{Themes concerning nursing care for institutionalized elderly people with dementia}

\section{Care focused on the needs of the elderly in Long-term care institutions for the elderly - LTCIEs}

This theme was informed by studies that had the objective to meet the needs of the elderly and provide individualized care in long-term institutions. Thus, the units of meaning were: a) preferences of the elderly in relation to care; attention to basic human needs; attention to cultural differences; identification of pain perception; systematization of nursing care; and involvement of the elderly in activities according to their individual potential.

In order to know the individual preferences of the elderly, the nursing team was encouraged to interact with the family, with the previous places of residence and teams that cared for the elderly before their admission to the long-term institution ${ }^{(13)}$. When possible, information about their preferences was collected from the elderly himself ${ }^{(13,46)}$. The exchange of experiences and systematic observation by members of the nursing team are also valuable sources of information. The diversity of professionals facilitates the use of different approaches, giving rise to more appropriate actions to assist the elderly in an individualized way, observing their preferences ${ }^{(23,50)}$.

The individual-based care process involves knowing the patterns of their basic human needs. For example: knowing eating habits involves discovering their favorite foods, where to serve them and who they wants to sit with during meals ${ }^{(37)}$. Bedtime routines include behaviors that precede the process of going to sleep, such as the choice of appropriate clothing, medication 
intake time and bath time, among others, that may contribute to a process closer to that which the elderly was already used to ${ }^{(48)}$.

A situation that is beginning to attract the attention of health teams is the fact that people are aging in countries other than their nationality, which can generate culture shocks and communication difficulties due to language. Considering the plurality of ethnicities found in some countries, the cultural standards of the institutionalized elderly may be different from those of the team. Thus, it is important that the nursing team seeks information about the cultural patterns of the country of origin of the elderly, such as food, intergenerational relationships and life habits. Madeleine Leininger's theory of the cross-cultural care model can assist in this process and guide nurses' practice ${ }^{(15,36)}$.

Pain management and assessment also need a more personalized approach, considering that pain manifests itself in different ways and each person has their own way of dealing with it. It is important to establish individualized measures for pain management and assessment in order to identify and establish the objectives of care $^{(13,42)}$.

The planning and systematization of nursing care must also be carried out considering the preferences and needs of each elderly person. This approach helps to choose the best forms of interaction with the elderly and to gain their trust. The correct identification of the elderly's problem requires a methodology to approach the problem found, which must be based on the systematization of nursing care and can be aided by instruments, protocols, guidelines or care programs. Wrong choices can worsen behavioral symptoms, as they cause discomfort or irritation $^{(11,20,23,25,27,30-31,35,41,43,46,49)}$.

One reason for the strong criticism of the LTCIEs is the lack of interventions designed to entertain the elderly. The researches found highlight the importance of promoting pleasurable and meaningful activities for the individual, based on their specific needs in conjunction with an assessment of their remaining skills. Only when chosen based on individual preferences will activities have a positive effect and promote the well-being of the elderly. The nursing team must also establish realistic expectations regarding the possible actions to be performed, based on the remaining skills of the elderly and their ability to interact and communicate ${ }^{(10,12-13,16,19,22,39)}$.

The studies also revealed research demands in the field of elderly-centered care. It is necessary to understand how this approach can help to reduce physical restrictions in the institutionalized elderly ${ }^{(45)}$, to establish a stronger relationship between elderly-centered care and increased quality of care ${ }^{(44)}$, and to find ways to ensure the implementation of existing strategies ${ }^{(14)}$.

This theme, Person Centred Care (PCC), is a strong trend in international nursing. It is a theoretical framework that guides care programs, such as Dementia Care Mapping (DCM) and Person Centred Nutritional Care, facilitating the process of thinking about nursing care with a focus on the elderly and their needs and preferences.

\section{Care based on the work progress of the nursing team}

The data that informs this theme is primarily focused on the nursing team and their actions with the elderly. Some characteristics were found to be essential for the care to take place. The units of meaning are: a) communication; b) support and training of the team; c) team values, skills, and attitudes; and d) the environment in which care takes place.

Communication between nurses and the elderly with dementia is different from communication in general with other patients. It can be affected by the cognitive difficulties of the elderly; their reduced capacity for understanding and verbal expression; cultural differences; and misunderstandings and nuances in communication $^{(15,29,36,38)}$. To be effective, the team can rely on established communication models, such as Marte Meo, Communication Enhancement Model ${ }^{(8,17)}$, theoretical knowledge about the factors involved in the verbal and non-verbal communication ${ }^{(22)}$ and the establishment of empathic communication ${ }^{(18,43)}$. A guideline on nursing care for patients with dementia addresses effective communication in a very comprehensive way, involving the factors mentioned above, also distinguishing the actions for each stage of the disease evolution, team self-evaluation concerning the results of interactions with the elderly, use of support tools, and the importance of the team's knowledge about dementia(20).

Team support takes place in three ways: facing stress in the workplace; hiring specialized teams to assist in the process of implementing new care processes; and investing in leadership training. One study reported the importance of stress relief for the nursing staff and how it positively influences the quality of care for the elderly with dementia ${ }^{(17)}$. The constitution of an internal team or the hiring of a team of external specialists in the area of interest will assist the team in loco in the implementation process, generating security towards the adopted measures. Institutional investment should also focus on establishing nursing leaders, so that they can lead the implementation and guide the team in this process ${ }^{(11,25,50-51)}$.

Team training has the main objective to assist in the process of implementing scientific evidence in clinical practice. This investment in the training of professionals involved in care allows changes to occur. Team training should occur continuously and include all professionals working on $\operatorname{LTCIEs}^{(12,14,16-17,32,51)}$.

Another aspect directly related to the care of the elderly are the skills and attitudes of the team. The skills required are: capacity for social support and interaction with the elderly, scientific knowledge about dementia, and systematic observation of the elderly ${ }^{(18,25,43)}$. Among other aspects, the family and the elderly expect the nursing team to demonstrate positive attitudes in care actions, being friendly, polite, generous, empathetic, and motivated to care. In their evaluation, these requirements are more important than scientific knowledge or performance of care actions. Therefore, the nursing professional is expected to "be present during care" instead of just performing care-related activities mechanically ${ }^{(19,33,39)}$.

Based on the discussions held about the care provided and the importance of the team's role in patient recovery, the nursing team, in the study by Lykkeslet et al., was able to recognize its own participation in the existence of residents, changing its role from mere observers of symptoms to establish and assume its role in the interaction with the elderly ${ }^{(38)}$.

In a study that evaluated the use of electronic surveillance in order to reduce the use of physical restrictions, it was found that 
the interaction and safety of the elderly are fundamental values for the nursing team. However, the researchers feared that this system would negatively influence the team's interaction with the elderly. Yet, the results showed that elderly safety and physical proximity are dominant values amongst the team, and the fear that electronic surveillance could decrease the care relationship proved unfounded ${ }^{(47)}$.

The environment where care is provided strongly influences its quality. Therefore, it should be thought of in a "macro" aspect the LTCIE should remind the elders of their domestic environment, preserving, whenever possible, their individual preferences. This environment should be safe and promote physical mobility, reducing the risk of falling and other accidents. In this regard, security begins in the structure of the building and must be established by physical devices, such as support bars in bathrooms, level floors and spacious and easily accessible elevator, as well as electronic devices such as sensors and alarms that warn the team about the movement of the elderly. In a micro vision of the LTCIE, each environment should be designed with the objective of providing the easy reach and visualization of the materials required to care or satisfice the needs of residents. The environment can also be considered a health promotion factor, when it enables and encourages healthy eating habits, hydration, mobility, and interaction between residents, staff and family ${ }^{(18,26,37)}$.

Although strongly based on nursing practice, this theme focuses on human care. As part of the profession of care, nursing teams should know the whole process by which interventions can help the elderly, and this happens through a close investigation of the aspects involved in nursing care.

\section{Shared care}

Consisting of shared care actions, this theme is composed by the following units of analysis: a) Shared care with the family; and b) Shared care with the multidisciplinary team. For shared care to occur, it is necessary to understand the approaches used.

In order to include the family in care, it is important to give it the necessary knowledge so that it can participate adequately and safely in the shared decision-making process. In the care model Goals of Care, the family watches explanatory videos about the objectives of care for people with dementia and the treatments available for each type of goal. Then, the nurse responsible for the elderly contacts the family, who reports their options, and both decide accordingly what will be the care objectives and the appropriate treatments for that specific case ${ }^{(28)}$.

Another way to favor family participation is to create institutional policies that allow them to participate in daily care - expanding visiting hours and allowing them to perform basic care when appropriate, valuing the information they have about the elderly. The family is an important source of information, because it knows how the elder was before developing dementia and can provide data on their history prior to the disease ${ }^{(18,29)}$.

In order to favor the multiprofessional care of the elderly, a research evaluated the use of the case study technique. Based on specific situations that the team is not being able to solve individually, the case is presented to the multidisciplinary team, which together seeks a solution to the problem ${ }^{(21)}$. A different possibility is using protocols and programs that favor the decision process shared with the team and with the users of the service, when possible ${ }^{(32,34)}$.

This theme presents a relevant issue for gerontological care: the importance of multidisciplinary work and of the family in promoting quality and evidence-based care. In this context, the problems presented by the elderly with dementia are found to cross the barriers of the knowledge of workers, requiring the team to work together, preferably with the involvement of family members, because they are the link between what the elderly experienced before dementia and their current state. That means that the memories of who the elders were, of the people they lived with, or of what they did are kept by family and friends, and only through them can one have access to such information in order to care for the elderly.

\section{DISCUSSION}

When analyzing the data presented in this integrative review, there is a growing interest from nursing professionals in the theme of caring for the elderly with dementia living in LTCIEs, because there was a constant increase in publications over the years, with wide distribution among the countries where studies were published.

Although the majority (44\%) used the quantitative methodology, qualitative studies and mixed methods also represented an important proportion of the approaches used, demonstrating the scope of nursing action and the need to use different methodologies to elucidate the issues pertinent to nursing care in the care of the elderly with dementia living in LTCIE.

Dementia is related to several etiologies, such as Alzheimer's disease, vascular and frontotemporal dementia, among others. However, the clinical framework of patients has common characteristics, such as cognitive decline, memory loss and difficulties in performing activities of daily living ${ }^{(52)}$. Among the non-cognitive symptoms, psychological and behavioral symptoms of dementia (PBSD) stand out, such as verbal/physical agitation, verbal/physical aggression, and resistance to care. In this review, PBSDs were present in $24.4 \%$ of the studies found. Scientific literature reveals that $75 \%$ of patients with dementia have at least one of these symptoms; and, during the five-year follow-up, it was found that $97 \%$ of the elderly experienced at least one of the symptoms, requiring focused action and technical preparation for them ${ }^{(53-54)}$.

The themes involved in the selected studies show valuable aspects of nursing care for the institutionalized elderly with dementia. The first is the importance of patient-centered care. Nursing should look at it from the perspective of the elderly, considering their basic needs, their culture and life prior to their institutionalization and the emergence of dementia, as well as their preferences for activities to be performed. The use of patient-centered care models has been shown to be effective in reducing PBSD, in addition to improving the quality of life of elderly people with dementia ${ }^{(55)}$.

Evidence shows the value of communication as an element of interaction and care. The team's skills and attitudes occupy a space as important as scientific knowledge in nursing practice, and should be improved in accordance with the needs of the individuals served. To achieve these goals, the team must be 
constantly trained and receive external support, when relevant. Although in the daily care practice of LTCIEs it is possible to observe a mere reproduction of hospital or home care, the studies highlight the particularities of this context and the need to generate knowledge based on this reality.

Hence, the quality of care provided to the elderly with institutionalized dementia can be enhanced through the inclusion of family and other professionals. The multiprofessional approach is essential for care and does not happen after a single look; on the contrary, it considers the individual as a multidimensional being. The expansion of the care perspective promoted by multiprofessional interventions favors the team, the elderly, and the family, in a process in which everyone benefits ${ }^{(56)}$

The three themes address nursing care from different perspectives: the preference of the elderly, the role of the nursing team, and multidisciplinary work. All of these perspectives need to be in line for the assistance to be provided safely and effectively.

\section{Study limitations}

Among the limitations of the study, there is the small number of researches. Further studies are suggested to include other approaches and forms of publication, such as reviews and qualitative researches, in addition to theses and dissertations.

\section{Contributions to the field of nursing}

This study contributes to nursing practice, as it draws attention to a theme present in the daily lives of teams working in long-term care facilities for the elderly: caring for the elderly with dementia. It emphasizes the need for care to be based on good scientific evidence so that it can be considered good nursing practice; as well as the importance of individualized care, centered on the elderly and their needs, as well as the training and communication of the team, and the role of the context.

\section{FINAL CONSIDERATIONS}

The results of this integrative review show several aspects related to the care provided to the elderly with dementia residing in LTCIEs. Patient-centered care has been gaining ground, either through theories and models of care, such as Person Centred Care, or through researches that highlight the importance of each individual's particular history.

The studies included in this review showed elderly with institutionalized dementia and the importance of integrating the family in nursing care, respecting their history, culture, and ability to share the care. This requires the nursing team to approach the family in order to promote family-team-elderly interaction, reducing the knowledge gaps about the individual's past life as a result. The knowledge derived from this interaction is used in planning care and activities for the elderly.

Nursing practice must be grounded on scientific evidence and systematic care. Theoretical nursing references must be chosen based on the demands of the team, the elderly, and the context of care. Behaviors and attitudes such as empathy, education, and motivation to interact with the elderly, have proven to be strong allies of nursing in offering humanized and quality care.

\section{REFERENCES}

1. World Health Organization. Risk reduction of cognitive decline and dementia: WHO guidelines. Geneva: World Health Organization. [Internet]. 2019 [cited 2019 Aug 19]. Available from: https://apps.who.int/iris/bitstream/handle/10665/312180/9789241550543-eng.pdf?ua=1

2. American Psychiatric Association. Diagnostic and statistical manual of mental disorders. 5th ed. Washington DC: American Psychiatric Press; 2013.

3. Alcântara AO, Camarano AA, Giacomin KC. Política Nacional do idoso: velhas e novas questões. Instituto de pesquisa econômica aplicada (IPEA)[Internet]. 2016 [cited 2019 Aug 19]. Available from: https://sbgg.org.br//wp-content/uploads/2016/10/Pol\%c3\%adtica-Nacional-doIdoso-velhas-e-novas-quest\%c3\%b5es-IPEA.pdf

4. Rodrigues MA, Santana RF, Paula RCC, Silva MTN, Espirito Santo FH. Exercício profissional de enfermagem em instituições de longa permanência para idosos: estudo retrospectivo. Texto Contexto Enferm[Internet]. 2018 [cited 2019 Aug 20];27(2):e1700016. Available from: http://www.scielo.br/pdf/tce/v27n2/0104-0707-tce-27-02-e1700016.pdf

5. Conselho Federal de Enfermagem (Cofen). Lei 7.498/86, de 25 de junho de 1986. Dispõe sobre a regulamentação do exercício da enfermagem e dá outras providências [Internet]. Brasília, DF: Cofen; 1986 [cited 2019 Aug 19]. Available from: http://www.cofen.gov.br/lein-749886-de-25-de-junhode-1986_4161.html

6. Lini EV, Portella MR, Doring M. Fatores associados à institucionalização do idoso: um estudo caso-controle. Rev Bras Geriatr Gerontol. 2016;19(6):1004-14. Available from: doi: 10.1590/1981-22562016019.160043

7. Mendes KDS, Silveira RCCP, Galvão CM. Revisão Integrativa: método de pesquisa para a incorporação de evidências na saúde e na enfermagem. Texto Contexto Enferm[Internet]. 2008 [cited 2018 Jan 23];17(4):758-64. Available from: http://www.scielo.br/pdf/tce/v17n4/18.pdf

8. Minayo MCS. Amostragem e saturação em pesquisa qualitativa: consensos e controvérsias. R.P.Q. [Internet]. 2017 [cited 2019 Aug 20];5(7). Available from: https://edisciplinas.usp.br/pluginfile.php/4111455/mod_resource/content/1/Minayosaturacao.pdf

9. Minayo MCS. Análise qualitativa: teoria, passos e fidedignidade. Cien Saude Colet[Internet]. 2012 [cited 2019 Aug 20];17(3). Available from: http://www.scielo.br/pdf/csc/v17n3/v17n3a07

10. Van Haitsma KS, Curyto K, Abbot KM, Towsley GL, Spector A, Kleban M. A randomized controlled trial for an individualized positive psychosocial intervention for the affective and behavioral symptoms of dementia in nursing home residents. J Gerontol B Psychol Sci Soc Sci[Internet]. 2015 [cited 2018 Jan 23];70(1):35-45. Available from: https://www.ncbi.nlm.nih.gov/pubmed/24304555 
11. McCabe MP, Bird M, Davison TE, Mellor D, MacPherson S, Hallford D, et al. An RCT to evaluate the utility of a clinical protocol for staff in the management of behavioral and psychological symptoms of dementia in residential aged-care settings. Aging Ment Health [Internet]. 2015 [cited 2018 Jan 23];19(9):799-807. Available from: https://www.ncbi.nlm.nih.gov/pubmed/25319535

12. Tjia J, Hunnicutt JN, Herndon L, Blanks CR, Lapane KL, Wehry S. Association of a Communication Training Program With Use of Antipsychotics in Nursing Homes. JAMA Intern Med[Internet]. 2017 [cited 2018 Jan 23];177(6):846-53. Available from: https://www.ncbi.nlm.nih.gov/pubmed/28418449

13. Hall GR, Gallagher M, Hoffmann-Snyder C. Bathing persons with dementia. lowa City (IA): University of lowa College of Nursing, John A. Hartford Foundation Center of Geriatric Nursing Excellence[Internet]. 2013 [cited 2018 Jan 23]. Available from: https://www.guideline.gov/ summaries/summary/44984?f=rss\&osrc $=12$

14. Jutkowitz, E, Brasure M, Fuchs E, Shippee T, Kane RA, Fink HA, et al. Care-delivery interventions to manage agitation and aggression in dementia nursing home and assisted living residents: a systematic review and meta-analysis. J Am Geriatr Soc[Internet]. 2016 [cited 2018 Jan 23];64:477- 88. Available from: https://www.ncbi.nlm.nih.gov/pubmed/27000321

15. Söderman M, Rosendahl SP. Caring for Ethnic Older People Living with Dementia - Experiences of Nursing Staff. J Cross Cult Gerontol[Internet]. 2016 [cited 2018 Jan 23];31:311-26. Available from: https://link.springer.com/article/10.1007\%2Fs10823-016-9293-1

16. Roberts G, Morley C, Walters W, Malta S, Doyle C. Caring for people with dementia in residential aged care: Successes with a composite person-centered care model featuring Montessori-based activities. Geriatr Nurs [Internet]. 2015 [cited 2018 Jan 23];36:106-10. Available from: https://www.ncbi.nlm.nih.gov/pubmed/25499658

17. Sprangers S, Dijkstra K, Romijn-Luijten A. Communication skills training in a nursing home: effects of a brief intervention on residents and nursing aides. Clin Interv Aging [Internet]. 2015 [cited 2018 Jan 23];10:311-19. Available from: https://www.ncbi.nlm.nih.gov/pmc/articles/PMC4309793/

18. Rodriguez-Martín B, Martínez-Andres M, Notario-Pacheco B, Martínez-Vizcaíno V. Conceptualizaciones sobre la atención a personas con demencia en residencias de mayores. Cad Saúde Pública[Internet]. 2016 [cited 2018 Jan 23];32(3):1-12. Available from: http://www.scielo.br/ pdf/csp/v32n3/1678-4464-csp-32-03-e00163914.pdf

19. Soderlund M, Cronqvist A, Norberg A, Ternestedt B, Hansebo B. Conversations between persons with dementia disease living in nursing homes and nurses - qualitative evaluation of an intervention with the validation method. Scand J Caring Sci [Internet]. 2016 [cited 2018 Jan 23];30:37-47. Available from: http://onlinelibrary.wiley.com/doi/10.1111/scs.12219/epdf

20. Registered Nurses Association of Ontario (RNAO). Delirium, dementia, and depression in older adults: assessment and care. Toronto, ON: Registered Nurses' Association of Ontario [Internet]. 2016 [cited 2018 Jan 23]. Available from: http://rnao.ca/sites/rnaoca/files/DDD_BPG.pdf

21. Palm R, Trutschel D, Simon M, Bartholomeyczik S, Holle B. Differences in Case Conferences in Dementia Specific vs Traditional Care Units in German Nursing Homes: results from a cross-sectional study. J Am Med Dir Assoc[Internet]. 2016 [cited 2018 Jan 23];17(1):91.e9e91.e13. Available from: http://www.jamda.com/article/S1525-8610(15)00557-5/pdf

22. Karel MJ, Teri L, McConnel E, Visnic S, Karlin BE. Effectiveness of Expanded Implementation of STAR-VA for Managing Dementia-Related Behaviors Among Veterans. Gerontologist[Internet]. 2016 [cited 2018 Jan 23];56(1):126-34. Available from: https://www.ncbi.nlm.nih.gov/pubmed/26185155

23. Van de Ven G, Draskovic I, Adang EMM, Donders R, Zuidema SU, Koopmans RTCM, et al. Effects of Dementia-Care Mapping on Residents and Staff of Care Homes: A Pragmatic Cluster-Randomised Controlled Trial. PloS ONE[Internet]. 2013 [cited 2018 Jan 23];8(7):e67325. Available from: https://www.ncbi.nlm.nih.gov/pmc/articles/PMC3699562

24. Moyle W, Venturato L, Cooke M, Murfield J, Griffiths S, Hughes J, et al. Evaluating the capabilities model of dementia care: A non-randomized controlled trial exploring resident quality of life and care staff attitudes and experiences. Int Psychogeriatr[Internet]. 2016 [cited 2018 Jan 23];28(7):1091-100. Available from: https://www.ncbi.nlm.nih.gov/pubmed/26960255

25. Cooke M, Moyle W, Venturato L, Walters C, Kinnane J. Evaluation of an education intervention to implement a capability model of dementia care. Dementia[Internet]. 2014 [cited 2018 Jan 23];13(5):613-25. Available from: https://www.ncbi.nlm.nih.gov/pubmed/24339075

26. Park M, Lim S, Kim E, Lee S, Chang S. Examining practical nursing experiences to discover ways in which to retain and invigorate the remaining functions of the elderly with a demented and complex disability in nursing homes. Jpn J Nurs Sci[Internet]. 2017 [cited 2018 Jan 23];15(1):77-90. Available from: http://onlinelibrary.wiley.com/doi/10.1111/jjns.12174/epdf

27. Kovach CR, Hekel B, Rababa M. Feasibility Testing of a Protocol to Stop Ineffective Drug and Nondrug Treatments. West J Nurs Res[Internet]. 2015 [cited 2018 Jan 23];37(11):1404-22. Available from: https://www.ncbi.nlm.nih.gov/pubmed/26250849

28. Hanson LC, Song MK, Zimmerman S, Gilliam R, Rosemond C, Chisholm L et al. Fidelity to a behavioral intervention to improve goals of care decisions for nursing home residents with advanced dementia. Clin Trials[Internet]. 2016 [cited 2018 Jan 23];13(6):599-604. Available from: http://journals.sagepub.com/doi/pdf/10.1177/1740774516650863

29. Rosendahl SP, Söderman M, Mazaheri M. Immigrants with dementia in Swedish residential care: an exploratory study of the experiences of their family members and Nursing staff. BMC Geriatr [Internet]. 2016[cited 2018 Jan 23];16(18):1-12. Available from: https://bmcgeriatr. biomedcentral.com/articles/10.1186/s12877-016-0200-y

30. Allen VJ, Methven L, Gosney M. Impact of serving method on the consumption of nutritional supplement drinks: randomized trial in older adults with cognitive impairment. J Adv Nurs[Internet]. 2014 [cited 2018 Jan 23];70(6):1323-34. Available from: http://onlinelibrary.wiley. com/doi/10.1111/jan.12293/full

31. Krumm N, Larkin P, Connolly M, Rode P, Elsner F. Improving dementia care in nursing homes: experiences with a palliative care symptomassessment tool (MIDOS). Int J Palliat Nurs [Internet]. 2014 [cited 2018 Jan 23];20(04);187-92. Available from: https://www.ncbi.nlm.nih.gov/ pubmed/24763327 
32. Finucane AM, Stevenson B, Moyes R, Oxenham D, Murray SA. Improving end-of-life care in nursing homes: Implementation and evaluation of an intervention to sustain quality of care. Palliat Med[Internet]. 2013 [cited 2018 Jan 23];27(8):772-8. Available from: http://journals. sagepub.com/doi/pdf/10.1177/0269216313480549

33. Koskenniemi J, Leino-kilpi H, Suhonen R. Manifestation of respect in the care of older patients in longterm care settings. Scand J Caring Sci[Internet]. 2015 [cited 2018 Jan 23];29(2):288-96. Available from: https://www.ncbi.nlm.nih.gov/pubmed/25213177

34. Jordan S, Gabe M, Newson L, Snelgrove S, Panes G, Picek A, et al. Medication Monitoring for People with Dementia in Care Homes: The Feasibility and Clinical Impact of Nurse-Led Monitoring. Scient World J [Internet]. 2014 [cited 2018 Jan 23]:2014. Available from: https:// www.hindawi.com/journals/tswj/2014/843621/

35. Jordan S, Gabe-Walter ME, Watkins A, Humphreys I, Newson L, Snelgrove S, et al. Nurse-Led Medicines' Monitoring for Patients with Dementia in Care Homes: A Pragmatic Cohort Stepped Wedge Cluster Randomised Trial. PloS One [Internet]. 2015 [cited 2018 Jan 23];10(10);1-27. Available from: https://www.ncbi.nlm.nih.gov/pmc/articles/PMC4603896/pdf/pone.0140203.pdf

36. Kim H, Woods DL, Phillips LR, Ruiz ME, Salem B, Jeffers-Skrine K, et al. Nursing assistants' communication styles in Korean American older adults with dementia: a review of the literature. J Transcult Nurs [Internet]. 2015 [cited 2018 Jan 23];26(2):185-92. Available from: http:// journals.sagepub.com/doi/abs/10.1177/1043659614547200

37. Murphy JL, Holmes J, Brooks C. Nutrition and dementia care: developing an evidence-based model for nutritional care in nursing homes. BMC Geriatr [Internet]. 2017[cited 2018 Jan 23];17(55):1-14. Available from: https://bmcgeriatr.biomedcentral.com/articles/10.1186/s12877-017-0443-2

38. Lykkeslet E, Gjengedal E, Skrondal T, Storjord M. 'On one's ownstrength' Healthcare providers' experience with introducing Marte Meo Counselling in dementia care. Int J Older People Nurs [Internet]. 2016 [cited 2018 Jan 23];11:24-31. Available from: http://onlinelibrary.wiley. com/doi/10.1111/opn.12085/epdf

39. Galik E, Resnik B, Hammersla M, Brightwater J. Optimizing function and physical activity among nursing home residents with dementia: testing the impact of function-focused care. Gerontologist[Internet]. 2014 [cited 2018 Jan 23];54(6):930-43. Available from: https:// academic.oup.com/gerontologist/article/54/6/930/564371

40. Boekhorst ST, Depla MFIA, Francke AL, Twisk JWR, Zwijsen SA, Hertogh CMPM. Quality of life of nursing-home residents with dementia subject to surveillance technology versus physical restraints: an explorative study. Int J Geriatr Psychiatry[Internet]. 2013 [cited 2018 Jan 23];28:356-63. Available from: https://www.ncbi.nlm.nih.gov/pubmed/22644773

41. Fitzsimmons S, Barba B, Stump M. Sensory and nurturing nonpharmacological interventions for behavioral and psychological symptoms of dementia. J Gerontol Nurs[Internet]. 2014 [cited 2018 Jan 23];40(11):9-15. Available from: https://libres.uncg.edu/ir/uncg/f/S_Fitzsimmons_ Sensory_2014.pdf

42. Peisah C, Weaver J, Wong L, Strukovski J. Silent and suffering: a pilot study exploring gaps between theory and practice in pain management for people with severe dementia in residential aged care facilities. Clin Interv Aging[Internet]. 2014 [cited 2018 Jan 23];9:1767-74. Available from: https://www.dovepress.com/silent-and-suffering-a-pilot-study-exploring-gaps-betweentheory-and-p-peer-reviewed-article-CIA

43. Mansah M, Coulon L, Bronw P, Reynolds $\mathrm{H}$, Kissiaw S. Tailoring dementia care mapping and reflective practice to empower assistants in nursing to provide quality care for residents with dementia. Aust J Adv Nurs[Internet]. 2014 [cited 2018 Jan 23];31(4):34-44. Available from: http://www.ajan.com.au/Vol31//ssue4/4Mansah.pdf

44. Rokstad AM, Rosvik J, Kirkevold O, Selbaek G, Saltyte Benth J, Engedal K. The effect of person-centred dementia care to prevent agitation and other neuropsychiatric symptoms and enhance quality of life in nursing home patients: a 10-month randomized controlled trial. Dement Geriatr Cogn Disord[Internet]. 2013 [cited 2018 Jan 23];36(5-6):340-53. Available from: https://www.alz.co.uk/sites/default/files/conf2014/OC003.pdf

45. Lejman E, Westerbotn M, Poder U, Wadensten B. The ethics of coercive treatment of people with dementia. Nurs Ethics [Internet]. 2013 [cited 2018 Jan 23];20(3):248-62. Available from: https://www.ncbi.nlm.nih.gov/pubmed/23329782

46. Fetherstonhaugh D, Tarzi L, Bauer M, Nay R, Beattie E. The Red Dress or the Blue?: how do staff perceive that they support decision making for people with dementia living in residential aged care facilities? J Appl Gerontol [Internet]. 2016 [cited 2018 Jan 23];35(2):209-26. Available from: https://www.ncbi.nlm.nih.gov/pubmed/24762711

47. Niemeijer AR, Depla M, Frederiks B, Francke AL, Hertogh C. The use of surveillance technology in residential facilities for people with dementia or intellectual disabilities: a study among nurses and support staff. Am J Nurs[Internet]. 2014 [cited 2018 Jan 23];114(12):28-37. Available from: https://www.ncbi.nlm.nih.gov/pubmed/25396755

48. Harris M, Grando V. When is nighttime? A description of bedtime in persons with dementia in the nursing home. Geriatr Nurs[Internet]. 2014 [cited 2018 Jan 23];35:474-8. Available from: http://www.gnjournal.com/article/S0197-4572(14)00221-3/fulltext

49. Lautenbacher S, Sampson EL, Pahl S, Kunz M. Which facial descriptors do care home nurses use to infer whether a person with dementia is in pain. Pain Med[Internet]. 2016 [cited 2018 Jan 23];18(11):1-11. Available from: https://www.ncbi.nlm.nih.gov/pubmed/28034977

50. Kolanowski A,Van Haitsma KS, Penrod J, Hill N, Yevchak A. Wish we would have known that! communication breakdown impedes personcentered care. Gerontologist [Internet]. 2015 [cited 2018 Jan 23];55(S1):50-60. Available from: https://academic.oup.com/gerontologist/ article/55/Suppl_1/S50/560959

51. Reichembach MT, Pontes L. Cenário e imagem da enfermagem baseada em evidências. Rev Bras Enferm [Internet]. 2018 [cited 2018 Jan 23];71(6):3026-7. Available from: http://www.scielo.br/pdf/reben/v71n6/pt_0034-7167-reben-71-06-2858.pdf

52. Ribeiro RM, Gusman F. Demência. In: Freitas EV, Mohalle MKL, Gamarski R, Pereira SRM. Manual prático de Geriatria. 2ed. Rio de Janeiro: Guanabara Koogan, 2017. p. 53-63. 
53. Lyketsos CG, Lopez O, Jones B, Fitzpatrick AL, Breitner J, Dekosky S. Prevalence of neuropsychiatric symptoms in dementia and mild cognitive impairment: results from the Cardiovascular Health Study. JAMA [Internet]. 2002 [cited 2019 Aug 19];288(12):1475-83. Available from: https://jamanetwork.com/journals/jama/fullarticle/195320

54. Steinberg M, Shao H, Zandi P, Lyketsos CG, Welsh-Bohmer KA. Point and 5-year period prevalence of neuropsychiatric symptons in dementia: the Cache County Study. Int J Geriatr Psychiatr[Internet]. 2008 [cited 2019 Aug 19];23(2). Available from: https://onlinelibrary. wiley.com/doi/epdf/10.1002/gps.1858

55. Kim SK, Park M. Effectiveness of person-centered care on people with dementia: a systematic review and Meta-analysis. Clin Interv Aging [Internet]. 2017 [cited 2019 Aug 19];12:381-97. Available from: https://www.ncbi.nlm.nih.gov/pmc/articles/PMC5322939/pdf/cia-12-381.pdf

56. Lourenço LFL. O significado do cuidado prestado pelos familiares aos idosos residentes em instituições de longa permanência para idosos. [Tese]. Universidade Federal de Santa Catarina; 2018. 